\section{OPEN JOURNAL SYSTEMS}

ISSN:2237-2202
Available on line at Directory of Open Access Journals

Journal of Hyperspectral Remote Sensing v.7, n.7 (2017) 399-407

www.periodicos.ufpe.br/revistas/jhrs

\section{Journal of Hyperspectral Remote Sensing}

\title{
Phenological Dynamics of Vegetation Using the Enhanced Vegetation Index (EVI) in Regions of Bahia State
}

\author{
Wanessa L. de B. Costa ${ }^{*}$, Célia C. Braga ${ }^{* *}$, Clênia R. Alcântara ${ }^{* * *}$, Adriana de S. Costa ${ }^{* * * *}$ \\ *Master in meteorology; Federal University of Campina Grande - UFCG, Av. Aprígio Veloso, 882. Bairro Universitário, Campina \\ Grande - PB, Brasil. E-mail: wanessaluanabc@ hotmail.com (Corresponding author) \\ ${ }^{* *}$ Professor of the Academic Unit of Atmospheric Sciences, UFCG. \\ **** Professor of the Academic Unit of Atmospheric Sciences, UFCG. \\ ${ }^{* * * * *}$ Doctoral candidate in meteorology, UFCG.
}

Received 13 June 2017; accepted 30 October 2017

\begin{abstract}
The purpose of this study is to analyze the dynamics of EVI (Enhanced Vegetation Index) variability in different time scales of the different biomes in the state of Bahia. Images of the MODIS / Terra (Moderate Resolution Imaging Spectroradiometer) sensor with spatial resolution of $1 \mathrm{~km}$ were used for the period between 2001 and 2015. For that, the methodology of the Wavelet Transformation (WT) was applied in each homogeneous region HR. The WT allows to identify in different scales important oscillations in the signal, through scales of energy and global power. Thus, it can be observed that the phenological pattern of vegetation predominates on an annual scale in almost all regions, except in HR1, HR4 and HR6 where interactions with smaller scales are detected: intrasazonal and seasonal to some years in the studied period. In this context, it was possible to identify that in the years where there were higher rates of EVI, there is an association with higher rainfall indices in different regions. Therefore, it can be said that EVI is also a good indicator of rainfall.

Keywords: Wavelet, Biomes, EVI.
\end{abstract}

\section{Introduction}

Climate variability has caused distinct influences on the development of civilizations over time. Full and dry plantations often devastated, which causes several losses of both social and economic character.

Frequent record of orbital sensor images covering large areas of the Earth's surface allows the elaboration and the analysis of temporal series of vegetation parameters, which can contribute to the investigation of the vegetation cover behavior of large areas, as well as, assist in the recognition of patterns and in the detection of possible changes or anomalies associated with anthropic or natural disturbances (Kuplich et al., 2013).

The vegetation cover of a given locality is related to the type of climate and predominant soil in this region which can be influenced by a set of factors such as: climate, relief, soil and its associated characteristics. In this way, several studies have been developed to estimate biophysical variables, through satellite images more accurately through vegetation indexes (Assis and Omasa, 2007; Bakr et al., 2010).

Vegetation indices are linear transformations of spectral bands, usually in the red (R) and near infrared (NIR) bands of the electromagnetic spectrum. According to Baret et al. (1989), these two bands have more than $90 \%$ of the vegetation spectral response variation.

Among the many existing vegetation indexes, the EVI (Enhanced Vegetation Index) stands out as one of the most used in the study of vegetation vigor. Suggested by Huete et al. (1997), obtained through MODIS (Moderate Resolution Imaging Spectroradiometer) sensor, aboard Terra and Aqua satellites was created in order to optimize the vegetation signal, improve sensitivity in regions with higher biomass density, besides the monitoring of the vegetation through a connection of the canopy bottom signal and the reduction of atmospheric influences (Latorre et al., 2003). The EVI responds mainly to the structural variations of the canopy, such as leaf area index, canopy type and architecture and plant 
physiognomy, in comparison with other vegetation indexes (Gao et al., 2000).

There are in the literature important tools for the analysis of time series of a range of different variables, among them are included statistical approaches such as main and spectral components, techniques such as Fourier analysis and the wavelet transform (WT), are also suitable for the study of different types of biomes (Kuplich et al., 2013).

WT is a mathematical function capable of decomposing and describing a series of temporal data at different time and frequency scales (Percival et al., 2004; Kuplich et al., 2013). According to Kuplich et al., (2013) it is commonly used in studies of meteorological data series, as it assists in the identification of cycles and frequency of occurrence, as well as, eventual disturbances in these cycles. It has been used to describe the seasonal dynamics of vegetation and the relationship between climate and phenology. "It is based on the adjustment of a curve in order to eliminate high frequencies associated with noise, remaining sensitive to changes in plant phenology (Antunes et al., 2010). Recently, Sousa (2016) has used techniques such as cluster analysis, principal component analysis and the wavelets transformation to analyze rainfall variability in the state of Minas Gerais. According to the author, WT allowed the visualization of important oscillations in the precipitation signal, showing the dominant components of rainfall variation in the study area.

Santos (2016) using a series of climatic precipitation in homogeneous regions of the state of Bahia, verified through the technique that not all homogeneous regions have the same rainfall regime, and also that in some regions of the State it rains practically the whole year, mainly in the south and southeast regions. Costa (2016) used WT to relate the variability of precipitation with sea surface temperature (SST) and other meteorological systems operating in the state of Maranhão. The results showed that the annual cycle was dominant in all the analyzed regions. The author also observed that in addition to the annual scale, there are interactions with the seasonal, intrasazonal, semi-annual, biannual and even decadal scales.

In this context, the objective of this study is to analyze the variability of the EVI obtained through the
MODIS/Terra sensor at different time / frequency scales, through WT in the period of 2001-20015, and make a connection with the different biomes of Bahia, in homogeneous regions of precipitation determined a priori.

\section{Materials and methods}

\subsection{Characterization of the study area}

The study area corresponds to the state of Bahia, located to the south of the Brazilian Northeast Region. It is a territory of approximately $600,000 \mathrm{Km}^{2}$, which is equivalent to $36.41 \%$ of the total area of the Northeast region. With almost 15 million inhabitants, it is the fourth most populous state in Brazil and the most populous in the Northeast (IBGE, 2015).

It borders to the south with the states of Espírito Santo and Minas Gerais, west of Tocantins and Goiás, north of Piauí and Pernambuco, northeast of Alagoas and Sergipe, and to the east by the Atlantic Ocean (Figure 1). Its capital, the city of Salvador, presents the highest number of natural disasters associated with intense rains on the northeast coast (Santos, 2008). The topography and the migration of different atmospheric systems give rise to a great variability space-time of the rains and the temperature on the State. The average annual air temperature is above $25^{\circ} \mathrm{C}$ in the north and less than $22{ }^{\circ} \mathrm{C}$ in the higher regions of Bahia plateau, in the Serra do Espinhaço and Chapada da Diamantina are less than 20 ${ }^{\circ} \mathrm{C}$ (INMET, 2015). Annual rainfall are greater than $1500 \mathrm{~mm}$ on the coast and less than $1000 \mathrm{~mm}$ inland, with the occurrence of even lower indices in certain specific regions, characterizing the semi aridity found in part of the region of the São Francisco valley (Neves et al., 2004).

Presents a relief consisting of plains, valleys, saws and mountains with altitude between $800 \mathrm{~m}$ and $1200 \mathrm{~m}$. The state has a very diverse vegetable cover that goes from the Caatinga in all the region north, depression of the São Francisco and saw of the Espinhaço, leaving to the cerrado only the western part and to the south and southeast the Atlantic Forest. The other regions of the state have farming activities, contacts between types of vegetation, Caducifólia forest and a small nucleus of Altitude Fields (Figure 2). 


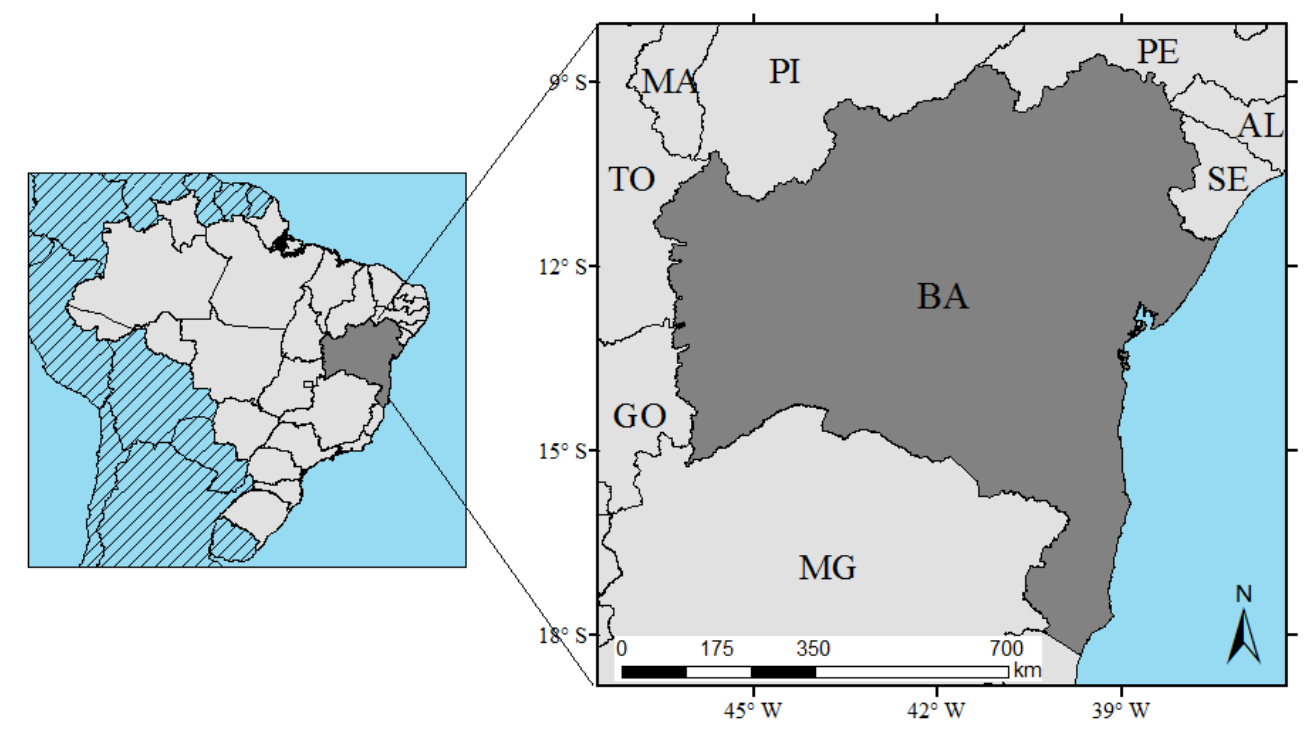

Figure 1 - Geographical location of the state of Bahia. Source: Costa (2017).

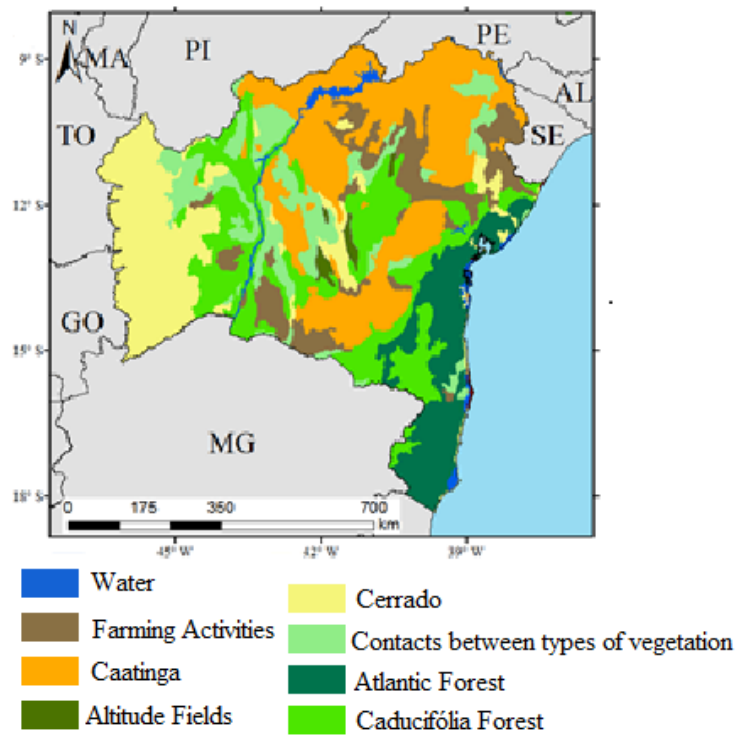

Figure 2 - Vegetation of Bahia State. Source: SEI (2001) adapted of COS'I'A (2017).

\subsection{EVI data}

The monthly EVI images were extracted from the MODIS / Terra sensor, specifically the product MOD13A3, with spatial resolution of $1 \mathrm{~km}$, for the period from January 2001 to December 2015, obtained through REVERB / ECHO at http://reverb.echo.nasa.gov/. Such products are in the HDF (Hierarchical Data Format) format, and were converted to IMG format. These are arranged in mosaic called "tiles". The state of Bahia due to its great extension is located in tiles h13v09, h13v10, h14v09, h14v10. The points were selected based on the geographical coordinates (latitude and longitude) coinciding with 104 pluviometric stations distributed throughout Bahia.

\subsection{Image Processing}

EVI Vegetation Index

According to Huete et al. (2002), vegetation indices are established to designate the vegetation properties and to grant reliable spatial and temporal comparisons of terrestrial photosynthetic activity and variations in crown structure, besides providing monitoring of seasonal and interannual phenological and biophysical parameters of vegetation in the long term. 
Among the many existing vegetation indexes, the EVI stands out as one of the most used today to study the vigor of vegetation. Suggested by Huete et al. (1997), obtained through the MODIS sensor on board the Terra and Aqua satellites, seeks to optimize the sign of vegetation, intensifying the response in regions with high concentration of biomass, improving atmospheric and ground interference, beyond of vegetation monitoring by means the a canopy background signal and the reduction of atmospheric influences (Justice et al., 1998; Latorre et al., 2003).

The EVI calculation is determined by the following expression:

$$
E V I=G \frac{\rho_{I V P}-\rho_{V e r}}{L+\rho_{I V P}+C_{1} \rho_{V e r}-C_{2} \rho_{a z u l}}
$$

where: $\mathrm{G}=$ gain factor $(2.5) ; \rho_{I V P}=$ near-infrared reflectance; $\rho_{V e r}=$ reflectance in red ; $\rho_{a z u l}=$ reflectance in blue; $\mathrm{C}_{1}=$ coefficient of adjustment for aerosol effect of the atmosphere for the red band (6); $\mathrm{C}_{2}=$ coefficient of adjustment for aerosol effect from the atmosphere to the band of blue (7.5); $\mathrm{L}=$ correction factor for soil interference. Theoretically, this index varies from 0 (referring to vegetation without leaf or exposed soil) to 1.0 (relative to leafy vegetation, without water restrictions and in fullness of its metabolic and physiological functions).

\section{The Wavelet Transform (WT)}

Arising in its continuous form in the 1980s with the works of Morlet and Grossman, WT is a tool that allows analyzing, detecting and characterizing the time scales of non-stationary oscillations. It is related to a set of functions in the form of small waves generated by translations $\psi(\mathrm{t}) \rightarrow \psi(\mathrm{t}+1)$ and escalations $\psi(t) \rightarrow \psi(2 t)$ of a base wave function $\psi_{0}(t)$, which has finite energy, in other words, it has beginning and end. This function is highly capable of dilating or compressing and is called mother-wavelet (Torrence and Compo, 1998; Blain and Kayano, 2011).

The base wave is formed by means of dilations and translations of a single wave:

$\psi_{\mathrm{j}, \mathrm{k}}(\mathrm{t})=\frac{1}{\sqrt{2}} \psi\left(\frac{t-k}{j}\right), \quad \mathrm{a}, \mathrm{b} \in \mathbb{R}, \quad \mathrm{a}>0$

where: $a$ is the scale and $b$ the position of the wave; $\frac{1}{\sqrt{a}}$ is called the energy normalization constant of each wave-daughter, so that together they maintain the same energy of the main wave $\psi(\mathrm{t})$, that is, the sum of the energies of all the wandering daughters.

The waving function must comprise the conditions of admissibility, that is, $\int_{-\infty}^{+\infty} \Psi_{0}(t) d t=0$ provide an average result of zero, and the wavelet function must be unitary $\int_{-\infty}^{+\infty}\left|\Psi_{0}(t)\right|^{2}=1$ de $-\infty$ a $+\infty$ (Daubechies, 1992; Oliveira et al., 2015).

In this study was applied the base wavelet "Morlet", which presents an excellent representation of non-stationary signals obtained in nature, such as symmetry, or not, and mild or abrupt temporal variation, which is given by equation 3, which represents a wave modulated by a Gaussian envelope, $t$ parameter (dimensionless) refering to the period or time scale under study and $\mathrm{W}_{0}$ (dimensionless) to the frequency of the signal.

$$
\Psi(t)=e^{i w_{0} t e^{-\frac{t^{2}}{2}}}
$$

\section{Results and discussion}

Based on studies by Costa (2017), which subdivided the state of Bahia into six homogeneous regions (HR) of EVI and precipitation, the variability of EVI in each HR was analyzed at different time / frequency scales by WT, for this the biomes present in each HR were considered (Table 1).

For the analysis of multiple frequency variability, the MORLET WT technique was used (Torrence and Compo, 1998; Bolzan, 2006). The observed result in the spectrum of energy and potency shows the differences in energy intensity between the types of biomes present in each HR, that even being in close areas present different behaviors.

The HR1, HR4 and HR6 located on the coast of Bahia even though they are close to each other, have different pluviometric regimes, that is, in HR1 and HR4 the highest rainfall occurs on average from april to august, while at HR6 from november to june. The highest average indices of $0.40,0.49,0.54$, respectively occur in these regions, when compared to the other coverages analyzed (Table 1). The predominant vegetation in these regions is the Atlantic Forest, besides small nuclei of Caducifólia forest. 
Table 1 - Characteristics of each homogeneous region

\begin{tabular}{ccccc}
\hline HR & Location & Average Annual Precipitation & Medium EVI & Predominant Biome \\
\hline HR1 & East & $1301.00 \mathrm{~mm}$ & 0.40 & $\begin{array}{c}\text { Atlantic Forest } \\
\text { Caducifólia Forest }\end{array}$ \\
$\mathbf{H R 2}$ & $\begin{array}{c}\text { Central Portion } \\
\text { North - South }\end{array}$ & $815.00 \mathrm{~mm}$ & 0.32 & Caatinga \\
$\mathbf{H R 3}$ & Extreme west & $841.00 \mathrm{~mm}$ & 0.36 & $\begin{array}{c}\text { Cerrado } \\
\text { Caducifólia Forest }\end{array}$ \\
$\mathbf{H R 4}$ & East Coast & $1869.00 \mathrm{~mm}$ & 0.49 & Atlantic Forest \\
HR5 & North - Central & $573.00 \mathrm{~mm}$ & 0.33 & Caatinga \\
\hline HR6 & Southeast -Coast & $1215.00 \mathrm{~mm}$ & 0.54 & Atlantic Forest \\
\hline
\end{tabular}

Source: Adapted from Costa (2017).

In the energy and power scales of WT for HR1 and HR4, the largest predominant energies occur in the annual cycle, according to Figures $3 \mathrm{~b}$ and $3 \mathrm{c}$. In addition to the annual scale, we observe interactions with the semester scales in the years 2006-2008 and 2012. Still a few disturbances are detected in the 2 and 4 year scales of 2004, 2010 and 2012 for both regions. In the years of 2004 and 2006 there are records of EN in 2007 and $2012 \mathrm{LN}$ and in 2010 there was a transition from EN to LN.

The analysis of the energy scalogram and
Power for RH6, situated on the south coast is quite different from the northern part. The annual cycle is dominant, but there are interactions with smaller semestral and seasonal scales in 2002 and 2004. From 2010 to 2012, the energies are much more intense in the semiannual and biannual scales. In this region, there are high rainfall rates, due to the performance of frontal systems (Santos, 2016) and other meteorological systems, causing large vegetation covering the region to remain green even in times of scarcer rainfall.
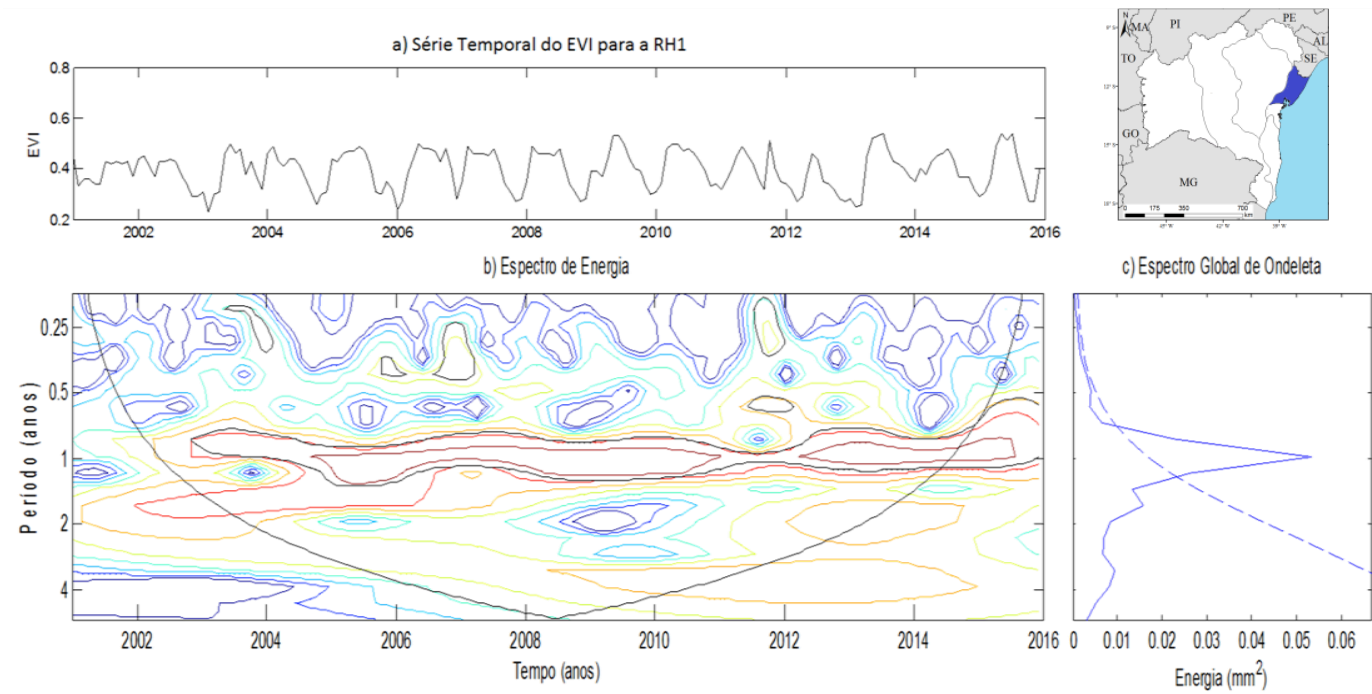

Figure 3 - a) Time series of the EVI for HR1, HR4, HR6, b) Scalar diagram of wavelet energy, c) Global spectrum. (Continue...) 

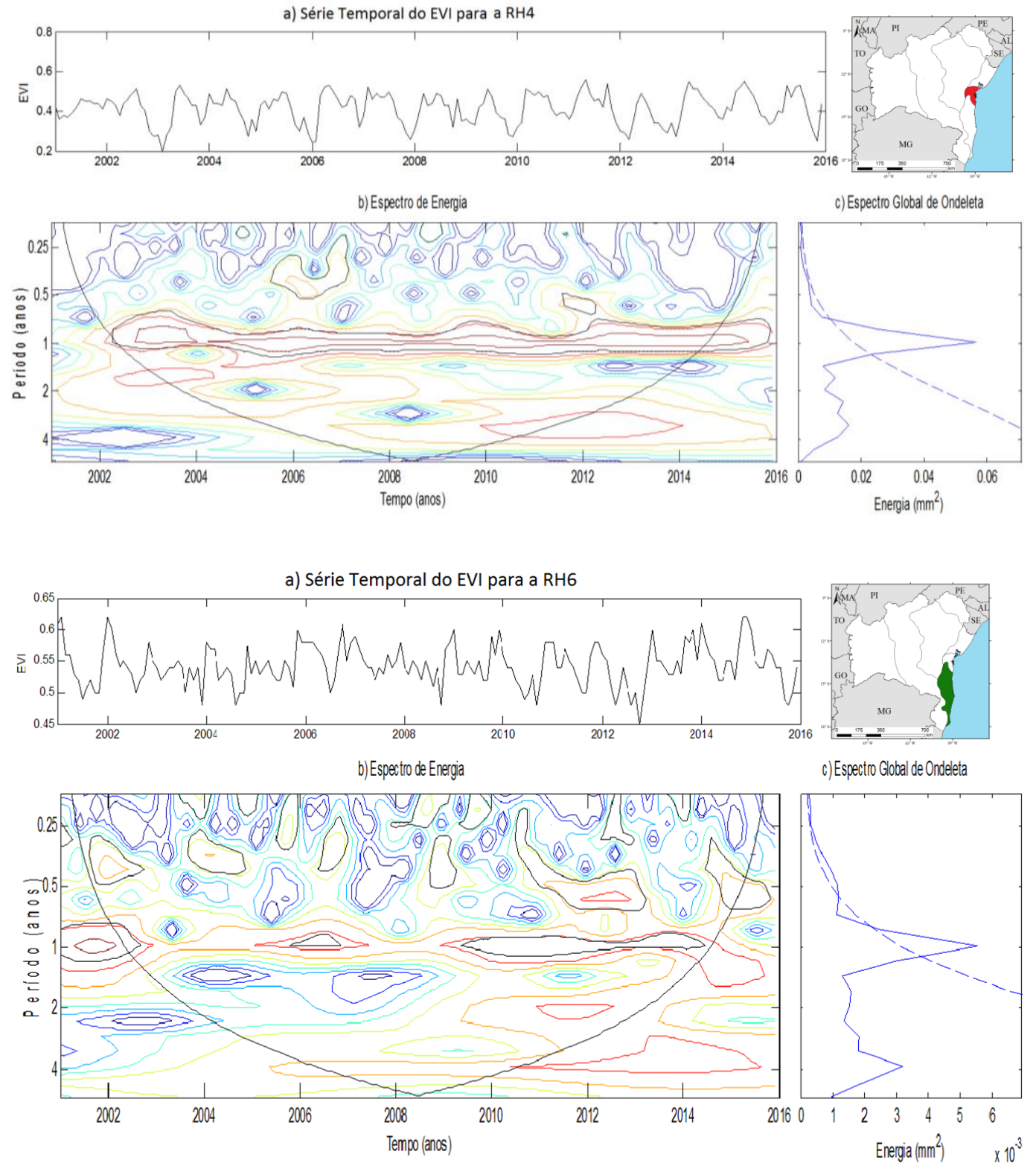

Figure 3 - a) Time series of the EVI for HR1, HR4, HR6, b) Scalar diagram of wavelet energy, c) Global spectrum. (Conclusion)

The HR2 located in the central region, extends from the North to the South of the State, whose predominant vegetation is caatinga type, although other types of vegetation are found such as: Caducifólia Forest, Atlantic Forest, Altitude Fields. It presents average annual precipitation total of $815.00 \mathrm{~mm}$ and mean EVI of 0.32 . The seasonal pattern of EVI generally follows, with decreasing values from summer to winter and resumption of plant vigor in spring and summer (Figure 4a).

In the energy and power scales, the annual cyclic pattern is denoted in every series (Figure 4-b and 4-c). There are still subtle interactions less than annual between 2003, 2012 and 2013, where EVI values were lower than the rest of the series (Figure 4-a). Possibly this change in the pattern is associated with the variability and concentration of the rain in a few months typical of semi-arid regions. 

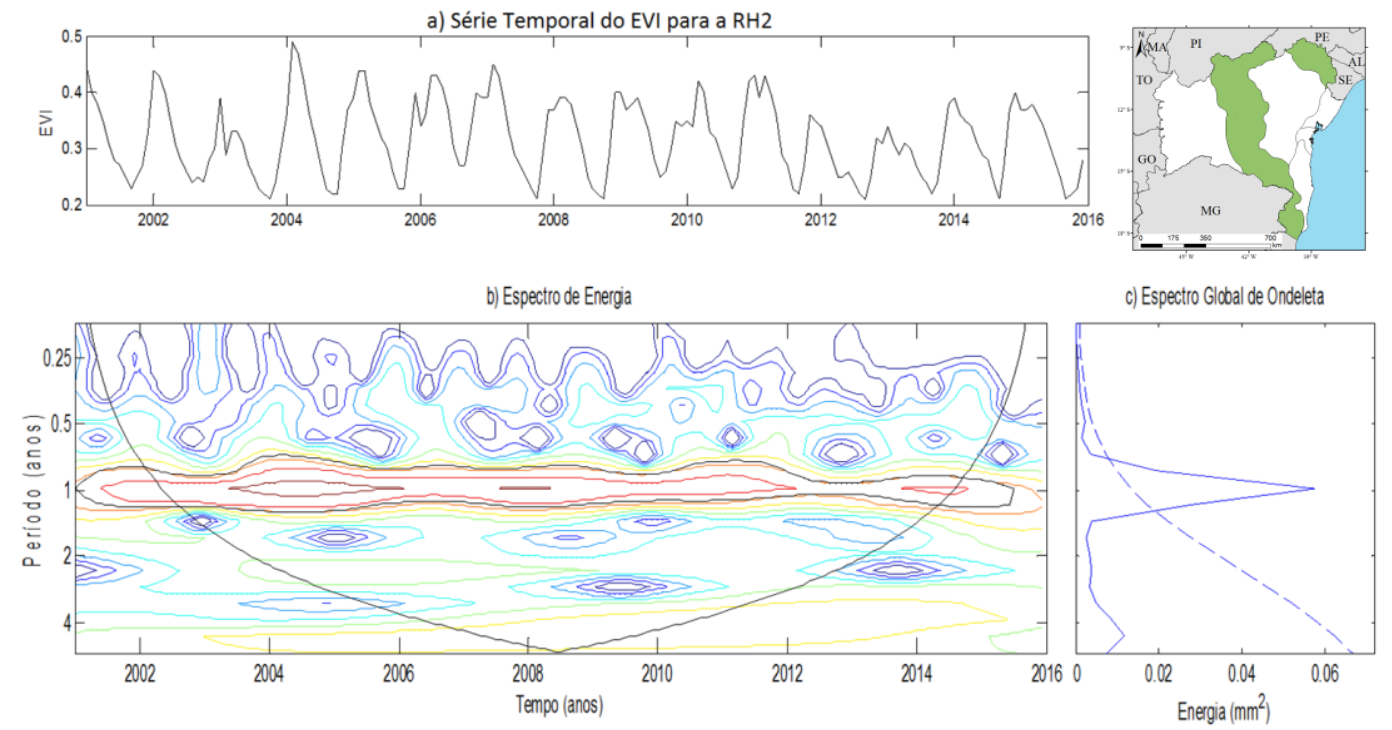

Figure 4- a) Time series of the EVI for HR2, b) Scale of wavelet energy, c) Global spectrum

The HR3 comprises the extreme west of Bahia, presents vegetation cover of the type Cerrado and Caducifólia forest. The mean annual rainfall is 841.00 $\mathrm{mm}$ and mean EVI is 0.36 , respectively. This region has behavior similar to HR2, without interactions with other scales, indicating EVI peaks in the rainy season and minimum in the dry season, independent of the years (Figure 5).
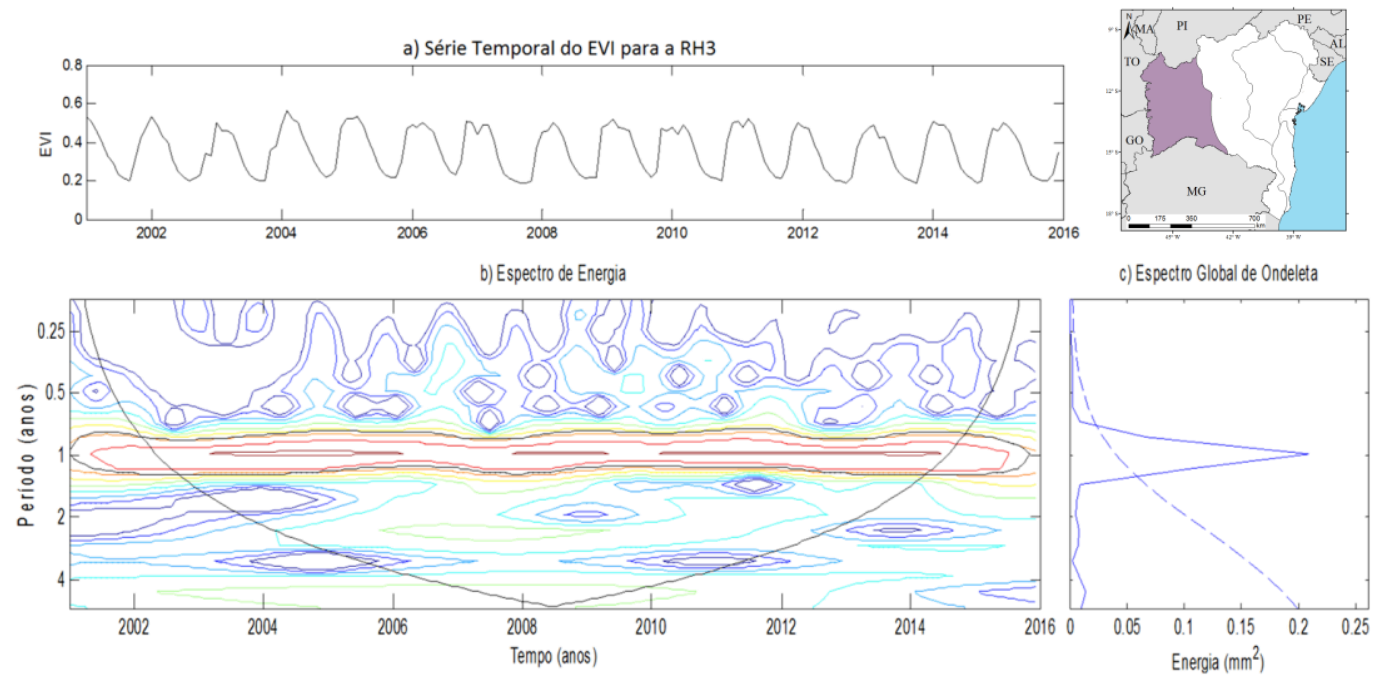

Figure 5- a) Time series of EVI for HR3, b) Scalar diagram of wavelet energy, c) Global spectrum.

The HR5 comprises the north central Bahia, stands out for presenting the lowest pluviometric indexes of the state, with an annual average of 573.00 $\mathrm{mm}$, and mean EVI of 0.33 . The predominant vegetation is the Caatinga, besides farming activities and Caducifólia forest (they lose their leaves during the dry season).

In HR5, the predominance of the annual scale is observed in the energy and power scales of WT, interacting with 4-year scales from 2008 to 2013 
(Figure 6-b and 6-c). Although part of these years is outside the cone of significance, vegetation in this region has been punished by the scarcity of rainfall caused by El Niño events in the last decade, especially in 2012-2013, when EVI values reached their minimums (Figure 6-a).
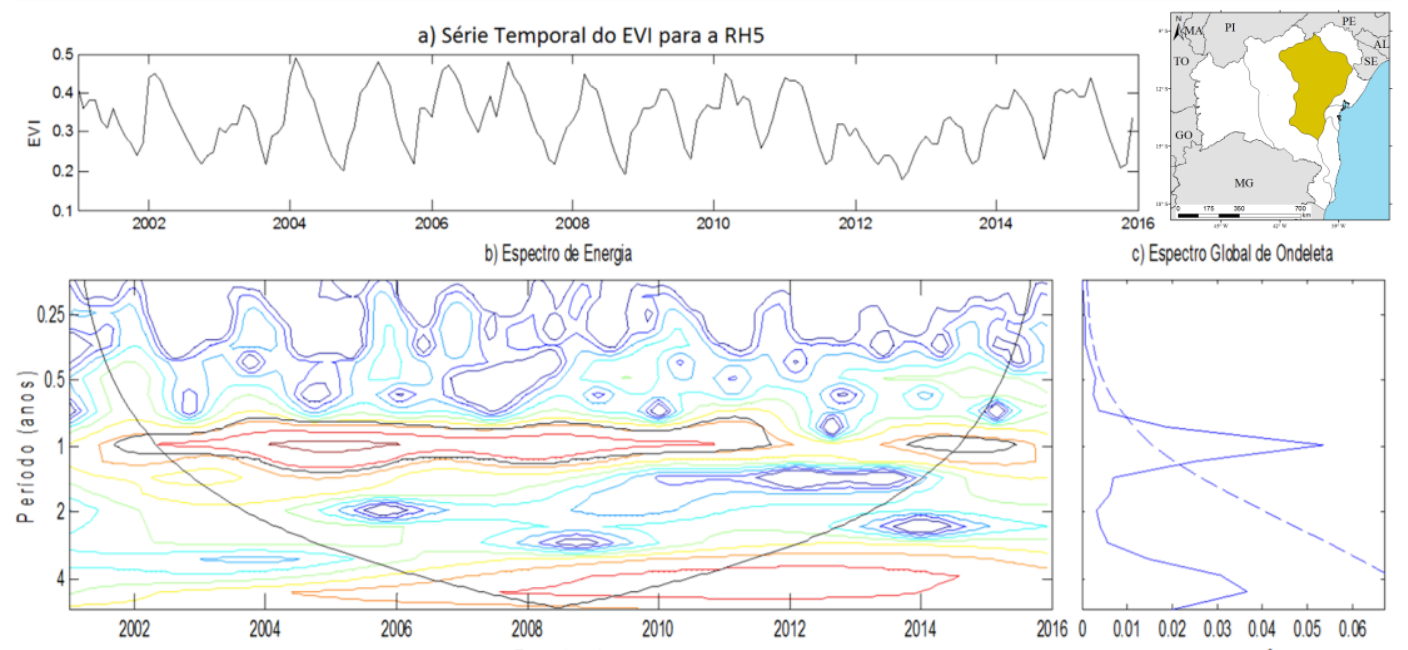

Figure 6- a) Time series of EVI for HR5, b) S Scalar diagram of wavelet energy, c) Globagal spectrum

The results found in this research corroborate with those obtained by Kuplich et al. (2013) in Rio Grande do Sul, where the data series presented annual cycles of greater vigor and plant growth in spring and summer and lower in autumn and winter. As well as those obtained by Amanajás (2015) in the cerrado of Amapá.

\section{Conclusions}

The application of the wavelet transform (WT) to the EVI data obtained from the MODIS / Terra sensor allowed to observed that the phenological pattern of the vegetation is consistent with the rainfall regime and the type of cover for each region. Although the time series studied was short (due to the lack of MODIS / Terra dataset), WT proved to be an effective mathematical tool in the detection of EVI frequencies and intensities through energy and potency scales in different regions of the state of Bahia.

\section{Acknowledgments}

The authors thank to Conselho Nacional de Desenvolvimento Científico e Tecnológico (CNPq) for the financial support granted to the research.

\section{References}

Blain, G.C., Kayano, M.T., 2011. 118 anos de dados mensais do Índice Padronizado de Precipitação: série meteorológica de Campinas, Estado de São Paulo. Revista Brasileira de Meteorologia 26, 137148.

Bolzan, M.J.A., 2006. Transformada em ondeleta: uma necessidade. Revista Brasileira de Ensino de Física 28, 563-567.

Costa, A.S., 2016. Modulação Regional das Chuvas no Estado do Maranhão. Dissertação (Mestrado). Campina Grande, UFCG.

Costa, W.L.B., 2017. Resposta de índices de vegetação as precipitações em diferentes regiões do estado da Bahia. Dissertação (Mestrado). Campina Grande, UFCG.

Daubechies, I., 1992. Ten Lectures on Wavelets. SIAM, NSF Conference Series in Applied Mathematics, Philadelphia.

Huete, A.R., Liu, H.Q., Batchily, K., Van Leeuwen, W.J.D.A., 1997. Comparison of vegetation indices over a global set of TM images for EOS-MODIS. Remote Sensing of Environment 59, 440-451.

Huete, A., Didan, K., Miura, T., Rodriguez, E.P., Gao, X., Ferreira, L.G., 2002 Overview of the radiometric and biophysical performance of the MODIS vegetation indices. Remote Sensing of Environment 83, 195-213.

IBGE. Instituto Brasileiro de Geografia e Estatística, 2015.
Disponível: 
http://ibge.gov.br/estadosat/perfil.php?sigla=ba. Acesso: 10 jul. 2015.

INMET. Instituto Nacional de Meteorologia, 2015. Disponível: http://www.inmet.gov.br/portal/. Acesso: 18 fev. 2015.

Justice, C.O., Running, S.W. et al., 1998. The Moderate Resolution Imaging Spectroradiometer (MODIS): Land Remote Sensing for Global Change Research. Ieee Transactions on Geoscience and Remote Sensing 36, 1228-1249

Kuplich, T.M., Moreira, A., Fontana, D.C., 2013. Série Temporal de índice de vegetação sobre diferentes tipologias vegetais no Rio Grande do Sul. Revista Brasileira de Engenharia Agrícola e Ambiental 17, 1116-1123.

Latorre, M.L., Anderson, L.O., Shimabukuro, Y.E., Carvalho Júnior, O.A., 2003. Sensor MODIS: características gerais e aplicações. Espaço \& Geografia 6, 97-126.

MODIS Website, 2016. Disponível: http://modis.gsfc.nasa.gov/. Acesso em: fevereiro de 2016.

Neves, D.G., Braga, C.C., 2004. Variabilidade Espacial e Temporal de IVDN para Região da Mata Atlântica no Estado da Bahia. Congresso Brasileiro de Meteorologia, Fortaleza.
Oliveira, J.V., Vitorino, M.I, Sá, L.D.A., 2015. Implication of Madden-Julian Oscillation phase on the Eastern Amazon climate. Atmosphere Science Letters 16, 318-323.

Santos, A.H.M., 2008. Eventos extremos de chuva em Salvador, Bahia: condições atmosféricas e impactos ambientais. Dissertação (Mestrado). Campina Grande, UFCG.

Santos, N.A., 2016. Modulação regional da precipitação e temperatura da superfície do mar no estado da Bahia. Dissertação (Mestrado). Campina Grande, UFCG.

SEI. Superintendência de Estudos Econômicos e Sociais da Bahia, 2015. Disponível: http://www.sei.ba.gov.br/index.php?option=com_co ntent\&view=ar ticle \&id=1901:fisicoambientais\&catid=1550\&Itemi $\mathrm{d}=498$. Acesso: 30 maio 2015.

Sousa, P.S., 2016. Padrões climáticos de eventos extremos de chuva utilizando análise multivariada e de ondeletas no estado de Minas Gerais Tese (Doutorado). Campina Grande, UFCG.

Torrence, C., Compo, G.P., 1998. A practical guide to wavelet analysis. Bulletin of the American Meteorological Society 79, 61-78. 